\title{
Testosterone Is a Contraceptive and Should Not Be Used in Men Who Desire Fertility
}

\author{
Amir Shahreza Patel ${ }^{1}$ (D) Joon Yau Leong ${ }^{2}$ (D) Libert Ramos $^{1}$ (D), Ranjith Ramasamy ${ }^{1}$ (D) \\ ${ }^{1}$ Department of Urology, University of Miami Miller School of Medicine, Miami, FL, ${ }^{2}$ Department of Urology, Thomas Jefferson University, \\ Philadelphia, PA, USA
}

\begin{abstract}
Testosterone has a variety of functions and is commonly used in older men to treat symptoms of hypogonadism, such as decreased libido, decreased mood and erectile dysfunction. Despite its positive effects on sexual function, it has a negative effect on fertility. Exogenous testosterone therapy can negatively affect the hypothalamic-pituitary gonadal axis and inhibit the production of follicle stimulating hormone and luteinizing hormone. The purpose of this review is to discuss the contraceptive properties of testosterone therapy and to discuss strategies to increase testosterone in men with the desire to preserve fertility.
\end{abstract}

Keywords: Contraception; Family planning services; Hypogonadism; Infertility; Testosterone; Testosterone replacement therapy

This is an Open Access article distributed under the terms of the Creative Commons Attribution Non-Commercial License (http://creativecommons.org/licenses/by-nc/4.0) which permits unrestricted non-commercial use, distribution, and reproduction in any medium, provided the original work is properly cited.

\section{INTRODUCTION}

Testosterone is a pleiotropic hormone that plays various physiological roles in the development of male genitalia in utero and during puberty. Classically, testosterone is a hormone associated with masculinity. Testosterone is used as treatment for males with late onset hypogonadism, a condition in men who experience symptoms caused by a decrease in serum testosterone. Symptoms associated with low testosterone can include decreased libido, decreased muscle mass, depressed mood and/or erectile dysfunction. The use of testosterone replacement therapy (TRT) among men over the age of 40 years has increased more than 3-fold over the last decade [1].
Exogenous testosterone comes in various preparations and each form carries various risks. Along with an increase in hematocrit, a major adverse effect of TRT is the diminished sperm production because of the decreased intra-testicular concentration of testosterone and suppression of the hypothalamic-pituitary-gonadal (HPG) axis [2-4]. Suppression of follicle stimulating hormone (FSH) release from the pituitary gland impairs sperm production and suppression of luteinizing hormone $(\mathrm{LH})$ release inhibits intra-testicular testosterone production.

The purpose of this review is to evaluate the contraceptive effect of testosterone, discuss how the use of exogenous testosterone can negatively impact a man's fecundity and identify the importance of family plan-

Received: May 4, 2018 Revised: Jun 22, 2018 Accepted: Jul 1, 2018 Published online Oct 10, 2018

Correspondence to: Amir Shahreza Patel iD https://orcid.org/0000-0002-6298-6421

Department of Urology, University of Miami Miller School of Medicine, 1120 NW 14th Street, Suite 1551, Miami, FL 33136, USA.

Tel: +1-305-497-7813, Fax: +1-305-243-6597, E-mail: asp136@med.miami.edu 
ning in men who are planning to receive TRT.

\section{PHYSIOLOGY OF TESTOSTERONE}

In healthy adult men, testosterone production is precisely regulated by the HPG axis. Higher cortical centers in the brain signal the hypothalamus to secrete gonadotropin-releasing hormone $(\mathrm{GnRH})$ in a pulsatile fashion. GnRH in turn stimulates the release of $\mathrm{LH}$ and FSH from the anterior pituitary which modulates testosterone production from the Leydig cells and spermatogenesis by the Sertoli cells, respectively. As testosterone levels increase, negative feedback suppression is exerted on the androgen receptors in the hypothalamic neurons and pituitary gland, thereby inhibiting the release of GnRH, FSH and LH [5].

The Endocrine Society and American Urological Association (AUA) recommends treating symptomatic men with low testosterone documented on two morning fasting serum total testosterone concentrations. Both organizations recommend against the use of testosterone for treatment of hypogonadism in men who desire fertility in the next 6 to 12 months [3,4].

The exogenous administration of testosterone suppresses the release of gonadotropins (FSH and $\mathrm{LH}$ ) to levels below that required for spermatogenesis. Spermatogenesis is largely dependent on the action of FSH on Sertoli cells coupled with high intra-testicular testosterone concentrations. Within the seminiferous tubules, only Sertoli cells possess receptors for both FSH and testosterone. Numerous signaling pathways are activated when FSH binds to FSH receptors on these cells. It acts synergistically with testosterone to increase fertility and the efficiency of spermatogenesis [6]. The inhibition of LH release by exogenous testosterone leads to the suppression of endogenous testosterone production by the Leydig cells. The decreased intra-testicular testosterone combined with the suppression of FSH leads to decreased germ cell survival and maturation (Fig. 1).

Intra-testicular testosterone is required in spermatogenesis for the formation of the blood-testis barrier (BTB). The BTB is a series of tight and adherens junctions between the Sertoli cells that separates postmeiotic germ cells in the adluminal compartment of the seminiferous tubules from the basal compartment containing the blood supply. During spermatogenesis, the BTB is disrupted and reformed as preleptotene spermatocytes pass through this barrier. In the absence of testosterone stimulation, spermatogenesis can only proceed as far as the prophase 1-leptotene stage of meiosis [7].

Testosterone is also required in maintaining connections between Sertoli cells and the haploid spermatid germ cells. Round spermatids are initially connected to Sertoli cells via desmosomes. As the spermatids mature and elongate, the desmosomes are replaced with stronger, specialized adherens junctions called ectoplasmic specializations, which are maintained until the release of mature sperm. Testosterone aids in this process and increases the efficiency of germ cell attachment to Sertoli cells. Testosterone is also essential for the release of mature spermatozoa from Sertoli cells. It has been shown that in the absence of testosterone stimulation, sperm are not released but are instead phagocytized by Sertoli cells [7].

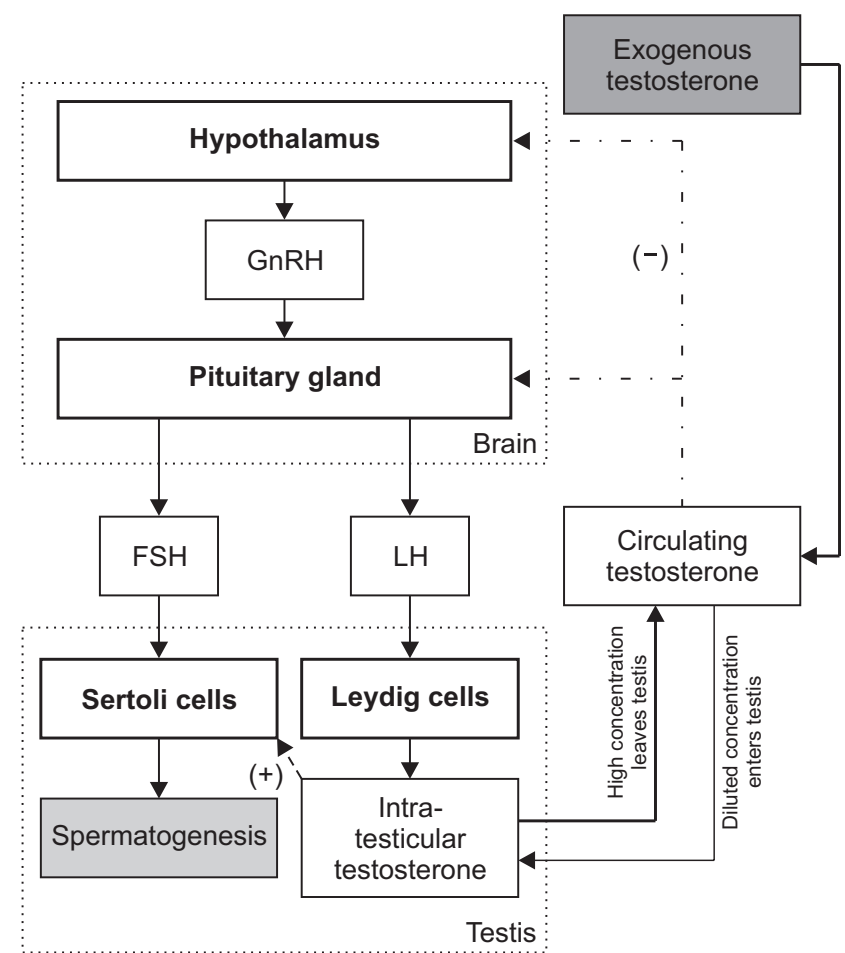

Fig. 1. Image explaining the contraceptive effect of exogenous testosterone. In summary, it works by 2 mechanisms, decreasing intratesticular testosterone, and inhibiting spermatogenesis. Most of the intra-testicular testosterone is made by the Leydig Cells in the testis. When exogenous testosterone is present, it inhibits gonadotropinreleasing hormone $(\mathrm{GnRH})$ production which in turn inhibits luteinizing hormone (LH) production and decreases endogenous testosterone production by the Leydig cells, decreasing the intra-testicular testosterone concentration. Inhibiting $\mathrm{GnRH}$ production also inhibits follicle stimulating hormone $(\mathrm{FSH})$ release, which impairs spermatogenesis in the Sertoli cells. 
Ultimately, the low intra-testicular testosterone results in decreased proliferation of spermatogonia, defects in spermiation of mature spermatozoa by Sertoli cells and accelerated apoptosis of spermatozoa [811]. Since $80 \%$ of testicular volume consists of germinal epithelium and seminiferous tubules, a reduction in these cells is usually manifested by testicular atrophy and this reflects the loss of both spermatogenesis and Leydig cell function [12,13].

Testosterone as a contraceptive can suppress spermatogenesis and lead to azoospermia in $65 \%$ of normospermic men within 4 months of use [14]. Cessation of exogenous testosterone will lead to the reversal of hormonally-induced azoospermia in $64 \%$ to $84 \%$ of men with a median time of about 110 days [13-15]. All men in these studies recovered to baseline levels after cessation of therapy; however, it took up to 2 years for some men to recover. These studies were performed in a controlled setting for a clinical trial, with a limited duration of testosterone use. In actual practice, recovery may not be as pronounced. Kohn et al [16] studied spermatogenesis recovery with human chorionic gonadotropin (hCG) and selective estrogen receptor modulators (SERM) in men with infertility associated with testosterone use. Thirty percent of the 66 men were not able to achieve a total motile sperm count of more than 5 million after 12 months in the study. They found that the failure of recovery is associated with older patients and longer TRT duration.

If fertility is affected because of TRT, couples may require the use of in vitro fertilization or intra-cytoplasmic sperm injection for future conception. These assistive reproductive technologies are expensive and are not always successful [17,18].

In summary, despite the androgenic effects of testosterone on sexual function, libido and mood; its effect on gonadotropins leads to the inhibition of sperm production [13]. This effect may diminish with the cessation of testosterone intake, but the extent of recovery is not clear for chronic users [16,19].

\section{TESTOSTERONE AS A MALE CONTRACEPTIVE}

Compared to the long list of contraceptive options available to women, men are limited to vasectomy and condoms. The former is challenging to reverse and the latter has failure rates as high as $18 \%$ because of non- compliance. Partners who correctly and consistently use condoms have failure rates of $2 \%$ [20,21]. As it is a user-dependent method, many couples seek easier to use options like female oral contraceptive pills or intrauterine devices [22]. However, there is a demand for alternatives. A survey of over 9,000 men from different populations in 2005 found that $29 \%$ to $71 \%$ of men are interested in using a form of hormonal male contraception $[22,23]$.

In 1978, a newly available oral testosterone preparation known as testosterone undecanoate (TU) was investigated as a possible form for male contraception. The study found that regular testosterone use for 10 to 12 weeks causes suppression of sperm production, and even azoospermia, albeit inconsistently [24]. Ever since that study, testosterone has undergone extensive clinical trials as a hormonal method of male contraception and many have found testosterone to be efficacious, reversible and safe with minimal short-term side effects [23].

Unfortunately, the contraceptive effect of testosterone is not reliable. This has been proven in multiple studies, including two by the World Health Organization (WHO) Task Force on Methods for the Regulation of Male Fertility [14,15,25]. These two studies found an azoospermia rate of $64 \%$ to $75 \%$ in 6 months with testosterone enanthate [6,7]. A sperm concentration of 3 million/mL was used as a threshold for effective suppression of spermatogenesis in this study $[14,15]$. In a Chinese study of a monthly intramuscular TU injection, an azoospermia rate of $93 \%$ to $98 \%$ was achieved after 6 months with 1 million/mL as the criteria for effective suppression [25,26]. The different rates of azoospermia can be explained by the variable criteria and by ethnic differences in testosterone response [26,27]. These studies confirm the effectiveness of testosterone as a contraceptive, and provides evidence that men who desire fertility should not be prescribed TRT.

Even with this evidence, testosterone has not been approved by the USA Food and Drug Administration (FDA) for use as a contraceptive. In 2011, a phase II study for a combined TU/norethisterone enanthate formulation ended prematurely because of higher than anticipated adverse effects including mood changes (such as depression), increased libido, acne and weight gain [27,28].

More recent advancements were shown in the 2018 Endocrine Society meeting, with dimethandrolone un- 
decanoate shown to effectively decrease sperm counts without adverse effects in a double-blind study in 2 academic sites. More extensive research on the safety of testosterone as a contraceptive needs to be done before testosterone can be used as a safe and reliable contraceptive [29].

\section{FORMULATIONS OF TESTOSTERONE REPLACEMENT THERAPY}

To date, many different testosterone formulations are available, each with their own side effect profiles. The selection of the preparation of testosterone requires a comprehensive discussion with the patient about the route of administration, cost and side effects of the individual formulations.

Oral methyltestosterone is the only form of oral testosterone approved for use in the USA. It is strongly associated with hepatotoxicity and the AUA recommends against using the formulation [2,3]. TU is approved for use in some countries but is not approved for use in the USA [4].

Topical options of TRT include gels and patches. They are relatively easy to administer and doses are able to be quickly altered when needed [30]. Their adverse effects include skin irritation seen with testosterone patches. Topical testosterone gels also run the risk of transference to others; but this can be avoided by using a clothing barrier [31,32].

Nasal testosterone gels (NTG) are a relatively newer form of TRT that is currently undergoing extensive research. It is seen to be advantageous over topical gels because of ease of use and the decreased risk of transference [33]. With regards to fertility, Conners et al [34] found that 4.5\% NTG two or three times a day restored serum testosterone levels while only decreasing gonadotropin levels minimally, keeping serum FSH and $\mathrm{LH}$ values within the normal range. Its short halflife results in a return of serum testosterone to near baseline levels between doses. It is theorized that this decreases its effect on the pulsatile release of $\mathrm{GnRH}$ by the hypothalamus [35]. A phase IV clinical trial is currently evaluating its impact on semen analysis parameters, and it would be the first study to do so [36]. Based on what is found by future studies, NTGs may have the potential to be a suitable TRT option in men desiring fertility.

Intramuscular testosterone injections are another form of TRT. These include testosterone cypionate and enanthate, which are self-administered once every 1 to 2 weeks. Their starting dose is $100 \mathrm{mg}$ weekly or 200 mg every two weeks before titrating in response to lab results on follow-up visits [3]. While the patients using these formulations will be able to avoid frequent trips to the clinic once the dose has been adjusted, it does require proper patient education to ensure compliance to the dose set by the healthcare provider. They also have a greater risk of side effects than other preparations [30,37]. One of these adverse effects is the "up and down' phenomenon due to the variable release of the hormone into the bloodstream leading to peaks and troughs beyond the normal range of serum testosterone levels [5,30,38,39].

TU is another preparation of intramuscular testosterone that is longer acting than the other formulations. It needs to be administered with an initial dose of $750 \mathrm{mg}$, followed 4 weeks later by another $750 \mathrm{mg}$ dose. This is then followed by an intramuscular injection once every 10 weeks. A disadvantage is that this preparation needs to be administered in the office as a slow injection over 2 minutes and patients need to be monitored for 30 to 45 minutes after administration due to the risk of developing pulmonary-oil micro embolism $[4,40]$.

Beyond gels, patches and injections, another option for TRT are the subdermal implants. They are administered in a 10- to 15-minute procedure in the office every three to six months depending on follow-up laboratory results. This is a popular option among patients because they do not have to self-inject or apply gels repeatedly [30]. It is particularly helpful in patients who travel regularly, and the extended release decreases the 'up and down' feelings often experienced with the intramuscular injections. The disadvantages of subdermal implants include the need for regular office visits, pain and bruising at the site of insertion, as well as the minimal risk of infection and pellet extrusion [30].

In terms of the contraceptive effect of the different formulations of testosterone, most research has shown that transdermal and intramuscular testosterone seem to be the strongest contraceptive formulations. The WHO and Chinese studies used testosterone enanthate and TU, respectively. The topical formulations of testosterone have variable contraceptive effects. The testosterone patch was shown to be an ineffective contraceptive [41] while the gel had mixed results $[42,43]$. 
However, the sample size for most of these studies are found in Table 1 [3,14,15,25,28,41-48]. not large enough to truly assess the extent to which fecundity is affected. More research needs to be done to evaluate the contraceptive effect of the various formulations of testosterone.

A list of the available testosterone formulations with its side effect profiles and effect on fertility can be

Table 1. List of testosterone formulations

\begin{tabular}{|c|c|c|c|}
\hline $\begin{array}{c}\text { Testosterone } \\
\text { formulations (brand) }\end{array}$ & $\begin{array}{l}\text { Dosage and } \\
\text { frequency }\end{array}$ & $\begin{array}{l}\text { Adverse } \\
\text { effects }\end{array}$ & $\begin{array}{c}\text { Contraceptive } \\
\text { effect }\end{array}$ \\
\hline Injectable & & $\begin{array}{l}\text { Inflammation and pain at } \\
\text { injection site }\end{array}$ & \\
\hline TE (Delatestryl) & $\begin{array}{l}50 \text { to } 200 \text { mg every one } \\
\text { to two weeks }\end{array}$ & $\begin{array}{l}\text { Serum levels tend to have } \\
\text { peaks and troughs }\end{array}$ & $\begin{array}{l}\text { A large multicenter trial of weekly TE alone is effective } \\
\text { in causing reversible azoospermia and severe } \\
\text { oligospermia without major side effects }[14,15] \text {. } \\
\text { Its contraceptive effect is more effective when } \\
\text { combined with } 500 \mathrm{mg} \text { oral levonorgestrel [44]. }\end{array}$ \\
\hline $\begin{array}{l}\text { Testosterone cypionate } \\
\text { (Depo-Testosterone) }\end{array}$ & $\begin{array}{l}50 \text { to } 200 \text { mg every one } \\
\text { to two weeks }\end{array}$ & $\begin{array}{l}\text { Avoid in soy } \\
\text { hypersensitivity }\end{array}$ & \\
\hline $\begin{array}{l}\text { Testosterone } \\
\text { undecanoate (Aveed) }\end{array}$ & $\begin{array}{l}\text { 750-mg initial dose and } \\
\text { another } 750 \text { mg four } \\
\text { weeks later, then } 750 \mathrm{mg} \\
\text { every } 10 \text { weeks }\end{array}$ & $\begin{array}{l}\text { Risk of anaphylaxis } \\
\text { and pulmonary oil } \\
\text { microembolism }\end{array}$ & $\begin{array}{l}\text { A Chinese study of monthly TU is effective in causing } \\
\text { reversible azoospermia and severe oligospermia } \\
\text { without major side effects [25]. WHO/CONRAD trial } \\
\text { testing TU/NETE (norethisterone enanthate) was } \\
\text { prematurely terminated due to adverse effects [28]. }\end{array}$ \\
\hline $\begin{array}{l}\text { Topical } \\
\text { Transdermal gel }\end{array}$ & & $\begin{array}{l}\text { Risk of transfer to others, } \\
\text { may cause application } \\
\text { site irritation }\end{array}$ & $\begin{array}{l}\text { Combined formulation with non-adrenergic progestin } \\
\text { gel (Nestorone) effective in causing reversible severe } \\
\text { oligospermia and azoospermia with minimal side } \\
\text { effects [42]. }\end{array}$ \\
\hline Androgel 1\% & 50 to $100 \mathrm{mg}$ daily & & A small study of 18 men found no change in semen \\
\hline Androgel $1.62 \%$ & 20.25 to $81 \mathrm{mg}$ daily & & parameters when using Androgel alone for the \\
\hline Fortesta $2 \%$ & 10 to 70 mg daily & & treatment of hypogonadism [43]. \\
\hline Testim 1\% & 50 to $100 \mathrm{mg}$ daily & & \\
\hline Vogelxo $1 \%$ & 50 to $100 \mathrm{mg}$ daily & & \\
\hline $\begin{array}{l}\text { Transdermal patch } \\
\text { (Androderm) }\end{array}$ & 2 to $6 \mathrm{mg}$ daily & $\begin{array}{l}\text { Skin rash common; } \\
\text { patients are advised to } \\
\text { rotate application sites }\end{array}$ & Not effective for use in contraception [41]. \\
\hline $\begin{array}{l}\text { Transdermal solution } \\
\text { (Axiron) }\end{array}$ & 30 to 120 mg daily & $\begin{array}{l}\text { Applied to axillary } \\
\text { region; risk of transfer } \\
\text { to others, may cause } \\
\text { application site irritation, } \\
\text { nasopharyngitis }\end{array}$ & \\
\hline $\begin{array}{l}\text { Buccal testosterone } \\
\text { (Striant) }\end{array}$ & $30 \mathrm{mg}$ twice daily & $\begin{array}{l}\text { May alter taste or irritate } \\
\text { gums and oral mucosa }\end{array}$ & \\
\hline Intranasal gel (Natesto) & $\begin{array}{l}33 \mathrm{mg} \text {; one actuation } \\
(11 \mathrm{mg}) \text { in each nostril } \\
\text { three times daily }\end{array}$ & $\begin{array}{l}\text { Adverse effects include } \\
\text { nasal irritation and upper } \\
\text { respiratory symptoms }\end{array}$ & \\
\hline $\begin{array}{l}\text { Subdermal pellets } \\
\text { (Testopel) }\end{array}$ & $\begin{array}{l}450 \text { to } 900 \text { mg every } \\
\text { three to four months }\end{array}$ & $\begin{array}{l}\text { May cause fibrosis, } \\
\text { bleeding, infection, } \\
\text { pellet extrusion }\end{array}$ & $\begin{array}{l}\text { Combined formulation with etonogestrel implants or oral } \\
\text { desogestrel lead to reversible azoospermia in most men } \\
\text { [45,46]. } \\
\text { Study shows decline in semen parameters after using } 800 \\
\text { mg testosterone implants [47]. } \\
\text { Contraceptive effect not affected by finasteride [48]. }\end{array}$ \\
\hline
\end{tabular}

Dosages are based on the 2018 American Urological Association Guidelines [3].

TE: testosterone enanthate, TU: testosterone undecanoate, WHO: World Health Organization. 


\section{USING TESTOSTERONE IN THE TREATMENT OF HYPOGONADISM IN MEN WHO DESIRE FERTILITY}

Considering that there is abundant evidence demonstrating that TRT significantly decreases sperm production, it is important that clinicians consider the evidenced risks of male infertility before starting patients on TRT. It can be surprising to patients that testosterone can suppress fertility, in contrary to its stimulatory effects on libido and erectile function. The patient's desire for fertility must be discussed in depth and established prior to initiating testosterone. The discussion must also include future thoughts on fertility. This will allow the physician to manage the timing of hypogonadism treatment, essentially balancing the alleviation of hypogonadal symptoms with the patient's desires for fertility. This could also open discussion about cryopreservation of sperm as an option for the patient to preserve fertility further down the line.

Physicians should also educate men already on TRT. There has been an increase in TRT use among men aged 18 to 45 years and more than $20 \%$ of these men did not get a baseline testosterone level prior to initiation of TRT [49]. Some of these men may not know about its effects on fertility and may not have discussed it with their prescribing physician. The study also showed that less than $2 \%$ of men on TRT obtained a baseline semen analysis [49]. In addition to the routine serum total testosterone, $\mathrm{LH}$, and hematocrit prior to starting TRT, every man of reproductive age should have a baseline semen analysis [3]. The baseline semen analysis will identify men with a decreased baseline sperm count, as a reference value for future semen analyses after TRT use.

If a patient currently desires fertility, TRT should be avoided or discontinued immediately. A semen analyses should be performed if the patient has discontinued TRT. Azoospermia or severe oligospermia may be seen in these patients, but most men should return to baseline semen analyses in 6 to 9 months after cessation of TRT [13-15]. A 2006 integrated analysis showed that $90 \%$ of patients were expected to return to baseline sperm concentration values 12 months after cessation of treatment and 100\% after 24 months [50]. Furthermore, evidence in a 2015 study of 49 men showed that 3,000 units of hCG subcutaneously every other day is effective in supporting the recovery of spermatogenesis without significant adverse effects [11].

Regardless, the recovery of spermatogenesis is unclear for patients on chronic TRT. Physicians should take caution when treating hypogonadism in men who desire future fertility, but also acknowledge the reversible azoospermia seen in controlled studies [51]. Adjunctive hCG and clomiphene can be used with TRT to maintain testicular size and intra-testicular testosterone concentrations [52]. Referral to a reproductive urologist should be considered in a male with low testosterone interested in fertility.

\section{ALTERNATIVES TO TESTOSTERONE THERAPY IN PATIENTS WHO WISH TO PRESERVE FERTILITY}

Clomiphene and enclomiphene citrate provide an alternative treatment option for hypogonadal men that desire fertility as it does not affect sperm production. Clomiphene is a non-steroidal SERM. It selectively binds to estrogen receptors in the hypothalamus, antagonistically inhibiting negative feedback, increasing the levels of gonadotropins and stimulating the testicular production of testosterone in men [53].

Even though enclomiphene citrate is not currently FDA approved, it has been shown to increase serum testosterone by raising the serum LH and FSH levels without negatively affecting semen parameters [54]. Kaminetsky et al [55] conducted a proof-of-principle, randomized, open-label, fixed dose, controlled, twocenter phase IIB study that compared $25 \mathrm{mg}$ of enclomiphene citrate daily to topical testosterone in hypogonadal men. The results showed higher testosterone levels and sperm counts in men receiving enclomiphene citrate. This corroborates with other studies which show improved semen parameters with the use of clomiphene citrate, with some studies describing it as a treatment for male infertility [56,57].

hCG has also been used (often with clomiphene citrate, tamoxifen or anastrozole) because it stimulates the production of endogenous testosterone without compromising spermatogenesis. Although the exact mechanism of action and production site in males are not fully understood, it is known that hCG mimics the effects of LH and stimulates the Leydig cells in the testicles to produce endogenous testosterone [3,58-60]. Additionally, studies have shown that low-dose hCG can be used with TRT to maintain high levels of intra- 
testicular testosterone while men are being treated for hypogonadism [52,61]. While hCG is effective in increasing testosterone, various studies have shown that it is also efficacious in inducing spermatogenesis [62,63]. It is even effective in helping with the recovery of spermatogenesis in men who were on TRT [11]. Clinicians generally agree on using 2,000 IU of hCG administered subcutaneously 3 times per week as defined by the 2002 American Association of Clinical Endocrinologists guidelines [64].

The ideal treatment for hypogonadism should provide physiological testosterone levels, exhibit appropriate circadian rhythms and be modulated by the HPG axis. No formulation of testosterone has been able to achieve this. However, there has been recent ongoing research on autograft Leydig stem cells. This may prove to be an effective treatment for hypogonadism in the future as it has the potential to fulfill all the criteria of an ideal TRT [65]. Makala et al [66] found that serum testosterone levels and Leydig cell populations were restored over time in mice who underwent ectopic autografting of testicular tissue. These results indicate that Leydig cells are able to regenerate de novo in the autografted adult testes, subsequently restoring serum testosterone level. In 2017, Zang et al [65] also demonstrated how direct transplantation of stem Leydig cells are capable of self-renewal, extensive proliferation and differentiation into mature Leydig cells. These Leydig cells can then be regulated by the HPG axis and restore the neuroendocrine regulation of testicular function and its diurnal testosterone production system. Having said that, these strategies still face major hurdles with regards to its clinical translatability and the ethics of cell transplantation.

\section{CONCLUSIONS}

Testosterone therapy is a contraceptive, albeit a poor one. Men of reproductive age with low testosterone should be counseled on the adverse effects of TRT on fertility. Obtaining a semen analysis and possible cryopreservation of sperm should be offered if TRT is prescribed to men interested in preserving fertility. Options such as clomiphene citrate and hCG along with a referral to a reproductive urologist should be considered to naturally increase testosterone levels in those men with low testosterone who want to avoid TRT.

\section{ACKNOWLEDGEMENTS}

The authors would like to thank the physicians and patients of Jackson Memorial Hospital, University of Miami Hospital, and the Miami VA for inspiring the creation of this review for clinician use.

\section{Disclosure}

The authors have no potential conflicts of interest to disclose.

\section{Author Contribution}

Conceptualization: Ramasamy R. Data curation: all authors. Formal analysis: all authors. Funding acquisition: none. Investigation: all authors. Methodology: all authors. Project administration: Ramasamy R. Resources: none. Software: none. Supervision: Ramasamy R. Validation: all authors. Visualization: all authors. Writing (original draft): all authors. Writing (review \& editing): all authors.

\section{REFERENCES}

1. Baillargeon J, Urban RJ, Ottenbacher KJ, Pierson KS, Goodwin JS. Trends in androgen prescribing in the United States, 2001 to 2011. JAMA Intern Med 2013;173:1465-6.

2. Westaby D, Ogle SJ, Paradinas FJ, Randell JB, Murray-Lyon IM. Liver damage from long-term methyltestosterone. Lancet 1977;2:262-3.

3. Mulhall JP, Trost LW, Brannigan RE, Kurtz EG, Redmon JB, Chiles KA, et al. Evaluation and management of testosterone deficiency: AUA guideline. J Urol 2018;200:423-32.

4. Bhasin S, Brito JP, Cunningham GR, Hayes FJ, Hodis HN, Matsumoto AM, et al. Testosterone therapy in men with hypogonadism: an Endocrine Society clinical practice guideline. J Clin Endocrinol Metab 2018;103:1715-44.

5. Basaria S. Male hypogonadism. Lancet 2014;383:1250-63.

6. Walker WH, Cheng J. FSH and testosterone signaling in Sertoli cells. Reproduction 2005;130:15-28.

7. Walker WH. Non-classical actions of testosterone and spermatogenesis. Philos Trans R Soc Lond B Biol Sci 2010;365: 1557-69.

8. Smith LB, Walker WH. The regulation of spermatogenesis by androgens. Semin Cell Dev Biol 2014;30:2-13.

9. Shaha C, Tripathi R, Mishra DP. Male germ cell apoptosis: regulation and biology. Philos Trans R Soc Lond B Biol Sci 2010;365:1501-15.

10. O’Donnell L, Nicholls PK, O’Bryan MK, McLachlan RI, Stan- 
ton PG. Spermiation: the process of sperm release. Spermatogenesis 2011;1:14-35.

11. Wenker EP, Dupree JM, Langille GM, Kovac J, Ramasamy R, Lamb D, et al. The use of HCG-based combination therapy for recovery of spermatogenesis after testosterone use. J Sex Med 2015;12:1334-7.

12. Cornud F, Amar E, Hamida K, Thiounn N, Hélénon O, Moreau JF. Imaging in male hypofertility and impotence. BJU Int 2000;86 Suppl 1:153-63.

13. Amory JK, Bremner W. Endocrine regulation of testicular function in men: implications for contraceptive development. Mol Cell Endocrinol 2001;182:175-9.

14. Contraceptive efficacy of testosterone-induced azoospermia in normal men. World Health Organization Task Force on methods for the regulation of male fertility. Lancet 1990;336: 955-9.

15. World Health Organization Task Force on Methods for the Regulation of Male Fertility. Contraceptive efficacy of testosterone-induced azoospermia and oligozoospermia in normal men. Fertil Steril 1996;65:821-9.

16. Kohn TP, Louis MR, Pickett SM, Lindgren MC, Kohn JR, Pastuszak AW, et al. Age and duration of testosterone therapy predict time to return of sperm count after human chorionic gonadotropin therapy. Fertil Steril 2017;107:351-7.e1.

17. Eftekhar M, Mohammadian F, Yousefnejad F, Molaei B, Aflatoonian A. Comparison of conventional IVF versus ICSI in non-male factor, normoresponder patients. Iran J Reprod Med 2012;10:131-6.

18. Komsky-Elbaz A, Raziel A, Friedler S, Strassburger D, Kasterstein E, Komarovsky D, et al. Conventional IVF versus ICSI in sibling oocytes from couples with endometriosis and normozoospermic semen. J Assist Reprod Genet 2013;30:251-7.

19. McBride JA, Coward RM. Recovery of spermatogenesis following testosterone replacement therapy or anabolic-androgenic steroid use. Asian J Androl 2016;18:373-80.

20. Kost K, Singh S, Vaughan B, Trussell J, Bankole A. Estimates of contraceptive failure from the 2002 National Survey of Family Growth. Contraception 2008;77:10-21.

21. Trussell J. Contraceptive failure in the United States. Contraception 2011;83:397-404.

22. Heinemann K, Saad F, Wiesemes M, White S, Heinemann L. Attitudes toward male fertility control: results of a multinational survey on four continents. Hum Reprod 2005;20:54956.

23. Wang C, Swerdloff RS. Hormonal approaches to male contraception. Curr Opin Urol 2010;20:520-4.

24. Nieschlag E, Hoogen H, Bölk M, Schuster H, Wickings EJ. Clinical trial with testosterone undecanoate for male fertility control. Contraception 1978;18:607-14.

25. Gu Y, Liang X, Wu W, Liu M, Song S, Cheng L, et al. Multicenter contraceptive efficacy trial of injectable testosterone undecanoate in Chinese men. J Clin Endocrinol Metab 2009; 94:1910-5.

26. Liu PY, Swerdloff RS, Anawalt BD, Anderson RA, Bremner WJ, Elliesen J, et al. Determinants of the rate and extent of spermatogenic suppression during hormonal male contraception: an integrated analysis. J Clin Endocrinol Metab 2008; 93:1774-83.

27. Kogan P, Wald M. Male contraception: history and development. Urol Clin North Am 2014;41:145-61.

28. Larkin A. Male hormonal contraceptive trial ending early [Internet]. Arlington (VT): CONRAD; c2011 [cited 2018 Jan 11]. Available from: http://www.conrad.org/news-pressreleases-63.html.

29. Thirumalai ACJ, Amory JK, Swerdloff RS, Surampudi V, Liu PY, Bremner WJ, et al. Pharmacokinetic and pharmacodynamic effects of 28 days of oral dimethandrolone undecanoate in healthy men: A prototype male pill. J Investig Med 2018;66:A165-6.

30. Srinivas-Shankar U, Sharma D. Testosterone treatment in elderly men. Adv Ther 2009;26:25-39.

31. Holyoak JD, Crawford ED, Meacham RB. Testosterone and the prostate: implications for the treatment of hypogonadal men. Curr Urol Rep 2008;9:500-5.

32. Stahlman J, Britto M, Fitzpatrick S, McWhirter C, Testino SA, Brennan JJ, et al. Serum testosterone levels in non-dosed females after secondary exposure to $1.62 \%$ testosterone gel: effects of clothing barrier on testosterone absorption. Curr Med Res Opin 2012;28:291-301.

33. Testosterone nasal gel (Natesto) for hypogonadism. Med Lett Drugs Ther 2015;57:73-4.

34. Conners W, Morgentaler A, Guidry M, Westfield G, Bryson N, Goldstein I. Preservation of normal concentrations of pituitary gonadotropins despite achievement of normal serum testoterone levels in hypogonadal men treated with a $4.5 \%$ nasal testosterone gel. The Journal of Urology 2017;197(4 Suppl):e1204.

35. Rogol AD, Tkachenko N, Bryson N. Natesto ${ }^{\mathrm{TM}}$, a novel testosterone nasal gel, normalizes androgen levels in hypogonadal men. Andrology 2016;4:46-54.

36. Ramasamy R. Natesto effects on testosterone, luteinizing hormone, follicle stimulating hormone and semen parameters [Internet]. Bethesda (MD): ClinicalTrials.gov [cited 2018 Jun 1]. Available from: https://www.clinicaltrials.gov/ct2/show/ NCT03203681?term=Intranasal+testosterone+semen\&ra $\mathrm{nk}=1$. 
37. Layton JB, Meier CR, Sharpless JL, Stürmer T, Jick SS, Brookhart MA. Comparative safety of testosterone dosage forms. JAMA Intern Med 2015;175:1187-96.

38. Di Luigi L, Sgrò P, Aversa A, Migliaccio S, Bianchini S, Botrè $\mathrm{F}$, et al. Concerns about serum androgens monitoring during testosterone replacement treatments in hypogonadal male athletes: a pilot study. J Sex Med 2012;9:873-86.

39. Snyder PJ, Lawrence DA. Treatment of male hypogonadism with testosterone enanthate. J Clin Endocrinol Metab 1980; 51:1335-9.

40. Middleton T, Turner L, Fennell C, Savkovic S, Jayadev V, Conway AJ, et al. Complications of injectable testosterone undecanoate in routine clinical practice. Eur J Endocrinol 2015; 172:511-7.

41. Gonzalo IT, Swerdloff RS, Nelson AL, Clevenger B, Garcia R, Berman N, et al. Levonorgestrel implants (Norplant II) for male contraception clinical trials: combination with transdermal and injectable testosterone. J Clin Endocrinol Metab 2002;87:3562-72.

42. Ilani N, Roth MY, Amory JK, Swerdloff RS, Dart C, Page ST, et al. A new combination of testosterone and nestorone transdermal gels for male hormonal contraception. J Clin Endocrinol Metab 2012;97:3476-86.

43. George M, Yulia T, Svetlana K. Influence of testosterone gel treatment on spermatogenesis in men with hypogonadism. Gynecol Endocrinol 2014;30 Suppl 1:22-4.

44. Bebb RA, Anawalt BD, Christensen RB, Paulsen CA, Bremner WJ, Matsumoto AM. Combined administration of levonorgestrel and testosterone induces more rapid and effective suppression of spermatogenesis than testosterone alone: a promising male contraceptive approach. J Clin Endocrinol Metab 1996;81:757-62.

45. Kinniburgh D, Zhu H, Cheng L, Kicman AT, Baird DT, Anderson RA. Oral desogestrel with testosterone pellets induces consistent suppression of spermatogenesis to azoospermia in both Caucasian and Chinese men. Hum Reprod 2002;17: 1490-501.

46. Brady BM, Walton M, Hollow N, Kicman AT, Baird DT, Anderson RA. Depot testosterone with etonogestrel implants result in induction of azoospermia in all men for long-term contraception. Hum Reprod 2004;19:2658-67.

47. Garrett C, Liu DY, McLachlan RI, Baker HW. Time course of changes in sperm morphometry and semen variables during testosterone-induced suppression of human spermatogenesis. Hum Reprod 2005;20:3091-100.

48. Kinniburgh D, Anderson RA, Baird DT. Suppression of spermatogenesis with desogestrel and testosterone pellets is not enhanced by addition of finasteride. J Androl 2001;22:88-95.
49. Rao PK, Boulet SL, Mehta A, Hotaling J, Eisenberg ML, Honig SC, et al. Trends in testosterone replacement therapy use from 2003 to 2013 among reproductive-age men in the United States. J Urol 2017;197:1121-6.

50. Liu PY, Swerdloff RS, Christenson PD, Handelsman DJ, Wang C; Hormonal Male Contraception Summit Group. Rate, extent, and modifiers of spermatogenic recovery after hormonal male contraception: an integrated analysis. Lancet 2006;367: 1412-20.

51. Ramasamy R, Armstrong JM, Lipshultz LI. Preserving fertility in the hypogonadal patient: an update. Asian J Androl 2015; 17:197-200.

52. Coviello AD, Matsumoto AM, Bremner WJ, Herbst KL, Amory JK, Anawalt BD, et al. Low-dose human chorionic gonadotropin maintains intratesticular testosterone in normal men with testosterone-induced gonadotropin suppression. J Clin Endocrinol Metab 2005;90:2595-602.

53. Pelusi C, Giagulli VA, Baccini M, Fanelli F, Mezzullo M, Fazzini A, et al. Clomiphene citrate effect in obese men with low serum testosterone treated with metformin due to dysmetabolic disorders: a randomized, double-blind, placebocontrolled study. PLoS One 2017;12:e0183369.

54. Rodriguez KM, Pastuszak AW, Lipshultz LI. Enclomiphene citrate for the treatment of secondary male hypogonadism. Expert Opin Pharmacother 2016;17:1561-7.

55. Kaminetsky J, Werner M, Fontenot G, Wiehle RD. Oral enclomiphene citrate stimulates the endogenous production of testosterone and sperm counts in men with low testosterone: comparison with testosterone gel. J Sex Med 2013;10:1628-35.

56. Chua ME, Escusa KG, Luna S, Tapia LC, Dofitas B, Morales M. Revisiting oestrogen antagonists (clomiphene or tamoxifen) as medical empiric therapy for idiopathic male infertility: a meta-analysis. Andrology 2013;1:749-57.

57. Roth LW, Ryan AR, Meacham RB. Clomiphene citrate in the management of male infertility. Semin Reprod Med 2013;31: 245-50.

58. Tamunopriye J, Abiola OO. Human chorionic gonadotrophin (HCG) stimulation test and testosterone response in children with micropenis. Pediatr Endocrinol Rev 2014;12:42-5.

59. Choi J, Smitz J. Luteinizing hormone and human chorionic gonadotropin: origins of difference. Mol Cell Endocrinol 2014;383:203-13.

60. Berger P, Gruschwitz M, Spoettl G, Dirnhofer S, Madersbacher S, Gerth R, et al. Human chorionic gonadotropin (hCG) in the male reproductive tract. Mol Cell Endocrinol 2007;260262:190-6.

61. Crosnoe-Shipley LE, Elkelany OO, Rahnema CD, Kim ED. Treatment of hypogonadotropic male hypogonadism: case- 
based scenarios. World J Nephrol 2015;4:245-53.

62. Rastrelli G, Corona G, Mannucci E, Maggi M. Factors affecting spermatogenesis upon gonadotropin-replacement therapy: a meta-analytic study. Andrology 2014;2:794-808.

63. Liu PY, Baker HW, Jayadev V, Zacharin M, Conway AJ, Handelsman DJ. Induction of spermatogenesis and fertility during gonadotropin treatment of gonadotropin-deficient infertile men: predictors of fertility outcome. J Clin Endocrinol Metab 2009;94:801-8.

64. Petak SM, Nankin HR, Spark RF, Swerdloff RS, RodriguezRigau LJ; American Association of Clinical Endocrinologists.
American Association of Clinical Endocrinologists Medical Guidelines for clinical practice for the evaluation and treatment of hypogonadism in adult male patients--2002 update. Endocr Pract 2002;8:440-56.

65. Zang ZJ, Wang J, Chen Z, Zhang Y, Gao Y, Su Z, et al. Transplantation of CD51+ stem Leydig cells: a new strategy for the treatment of testosterone deficiency. Stem Cells 2017;35:122232.

66. Makala H, Pothana L, Sonam S, Malla A, Goel S. Regeneration of Leydig cells in ectopically autografted adult mouse testes. Reproduction 2015;149:259-68. 